\title{
The evolution of farm policies: a long-term global perspective
}

Niek Koning

Wageningen University

May 17, 2007

\section{Farm progress in the pre-industrial era}

Agriculture's importance for welfare and food security has always provoked government intervention. However, the nature of this has undergone profound changes and may change again in the future. In pre-industrial societies, governments taxed rather than supported their farmers (Olson 1985). Apart from large infrastructural projects, they did little to encourage farm progress. The 'agricultural revolutions' through which these societies went - from slash-and-burn systems to sophisticated rotations with zero fallow (Mazoyer \& Roudart 1997) - followed from private activities by farmers and landowners.

These agricultural revolutions had various drivers and conditions - population growth, environmental change, the previous exploration of technical options - and involved changes in social structures that stimulated or hampered further development (Johnson \& Earle 2000; Schutkowski 2006; Wood 1998). However, an important condition that allowed agricultural revolutions in pre-industrial market economies to occur was Ricardo's law that, given the dearth of fertilizer and the costliness of transport, population growth raised agricultural prices and cheapened farm labour (Ricardo 1817). ${ }^{1}$ It stimulated larger farmers to intensify, to innovate, and to expand their share in production. It also created rural markets for commerce and industries and generally enhanced market exchange, which accelerated the diffusion of innovations.

In this way, agricultural revolutions were possible even when government policies were not especially 'enabling'. To be sure, because knowledge infrastructure was little developed and high risks enhanced the weight of tradition, collective learning was a slow process. Sooner or later, an agricultural revolution exhausted the cognitive and institutional capabilities of a society. Then food prices skyrocketed, squeezing the demand for non-farm products, making unemployed artisans swell the ranks of small farmers, and inducing the latter to over-exploit their plots in an effort to minimize their dependence on food markets (cf. Meuvret 1946). Society was pushed into a Malthusian spiral of soil degradation, food insecurity and disruption that ended in demographic stagnation or collapse. This drove food prices down and raised wages, temporarily reversing the process of intensification - until a new demographic upswing initiated a new cycle. ${ }^{2}$

\section{Global industrialization and the need for "enabling farm policies"}

The Industrial Revolution did not immediately break this Malthusian regime. Its textile factories and horse-drawn transport stimulated the demand rather than the supply of farm products,

\footnotetext{
${ }^{1}$ See Shiel (1991) for a good explanation of the difficulty to raise yields in the pre-fertilizer era.

${ }^{2}$ See Abel (1978), Grigg (1980) and Slicher van Bath (1963) for long-term fluctuations in pre-industrial market economies.
} 
reinforcing the effect of population growth on agricultural markets. Between 1775 and 1875, agricultural prices remained high, farm wages were low, and larger farms kept the lead in farm progress. Farm innovations remained a product of practical entrepreneurs in and around farming (Koning 1994). Leading soil chemist Liebig urged a division between farm practice and agricultural science, but his message was precocious (Schling-Brodersen 1989) ${ }^{3}$ and a prominent research station like Rothamsted (UK) remained close to practical farm entrepreneurship (Sykes 1981). Agriculture became the focus of the ascending economic liberal model. Common lands were divided, property rights commercialized, government bodies privatized, and tollhouses abolished. The repeal of the British Corn Laws (1846) heralded a worldwide liberalization of agricultural trade. In Britain, it stabilized agricultural prices without entailing a price decline. It did not hamper the Victorian 'high farming' revolution - the beginning of external input agriculture still in a framework of large farms (Crosby 1977; Moore 1965).

All this changed when a new phase of the Industrial Revolution broke the Ricardian connection between population and prices (Schultz 1945; Koning 1994). From the later $19^{\text {th }}$ century, cheap transport and industrial fertiliser boosted global farm supply; electricity, industrial chemistry, and internal combustion caused minerals to replace farm-produced materials; and industrial competition in agricultural labour markets strongly increased. It led to falls in agricultural prices and rises in farm wages that caused a squeeze on farm profits (see Figures 1 and 2 for illustration). Limited economies of size hampered a correcting shake out of small farms. While low profits eroded the technical lead of large farms, rising wages reinforced the advantage that small farms derived from cheap family labour. As a consequence, the share of the latter in agricultural production increased (Dovring 1965; Smith 1970). Rather than leaving a sector with low earnings, smallholder households tightened their belts and seized upon the new technical and market opportunities to defend their incomes by raising production - initiating a treadmill by which their incomes were permanently depressed (Cochrane 1959). ${ }^{4}$ In a free market, a balance between the growth in supply and that in demand was only achieved when this treadmill squeezed its own fuel supply by reducing farm profits and thereby investment. Rather than to the efficient equilibrium of the standard economic model, it led to crowding and slowdown of farm progress.

These developments induced profound policy changes in western countries (Koning 1994; Tracy 1989). Liberal land reform gave way to redistributive measures that streamlined the shift from large farms to family farms. Government sponsored experiment stations, farm schools and extension agents took over the role of large farmers and landowners as initiators of innovation. Moreover, governments intervened to moderate the fall in agricultural prices. These responses followed diverging pathways in different countries. Redistributive land reform went much further in some countries than in other ones, and the time in which they introduced agricultural development policies and protection differed.

In the late $19^{\text {th }}$ century, most West European countries resorted to protection to shield their farmers from the fall in international agricultural prices. Other western countries still kept to agricultural free trade in this period. Most of them had special advantages in the farm sector. Rather than resorting to protection, many of them introduced policies to encourage innovations. Thus in the United States, the Hatch Act of 1887 laid the base for the agricultural experiment

\footnotetext{
${ }^{3}$ This was also shown by his own failure to produce effective fertilizers.

${ }^{4}$ Various conditions explain why small farmers do not easily leave agriculture. In an early phase of development, a squeeze on farm earnings that hinders investment in agriculture also hampers the increase in industrial jobs, locking a large part of the population into rural poverty. Once industrialisation has been initiated, many people will still be tied to the land. Imperfect information makes it rational for industrial employers to pay higher than market-clearing wages ('efficiency wages') to secure the loyal dedication of workers (Akerlof and Yellen 1986). This causes obstacles such as unemployment for farm workers who want to change jobs. In addition, a profit squeeze may drive out larger farm entrepreneurs, leaving agriculture to household producers, who are less mobile than hired workers (Koning 1994). Social-psychological adaptation also plays a role. For instance, Haagsma and Koning (2002) show how temporary transition barriers (like temporary mass unemployment) may provoke occupational preference norms that become selfreinforcing.
} 
stations while the Morrill Act of 1890 greatly expanded the funding of the land grant colleges (Rossiter 1979). In the Netherlands, the establishment of a State Commission on Agriculture in 1886 heralded the establishment of experiment stations, extension services and public farm schools (Directie van den Landbouw 1907). Both countries weathered the price fall, and when international prices recovered after 1900, dynamic agricultural development resumed.

Figure 1. Real wheat prices (5-year moving average) and farm wages, England and Wales, 1818 $=100$

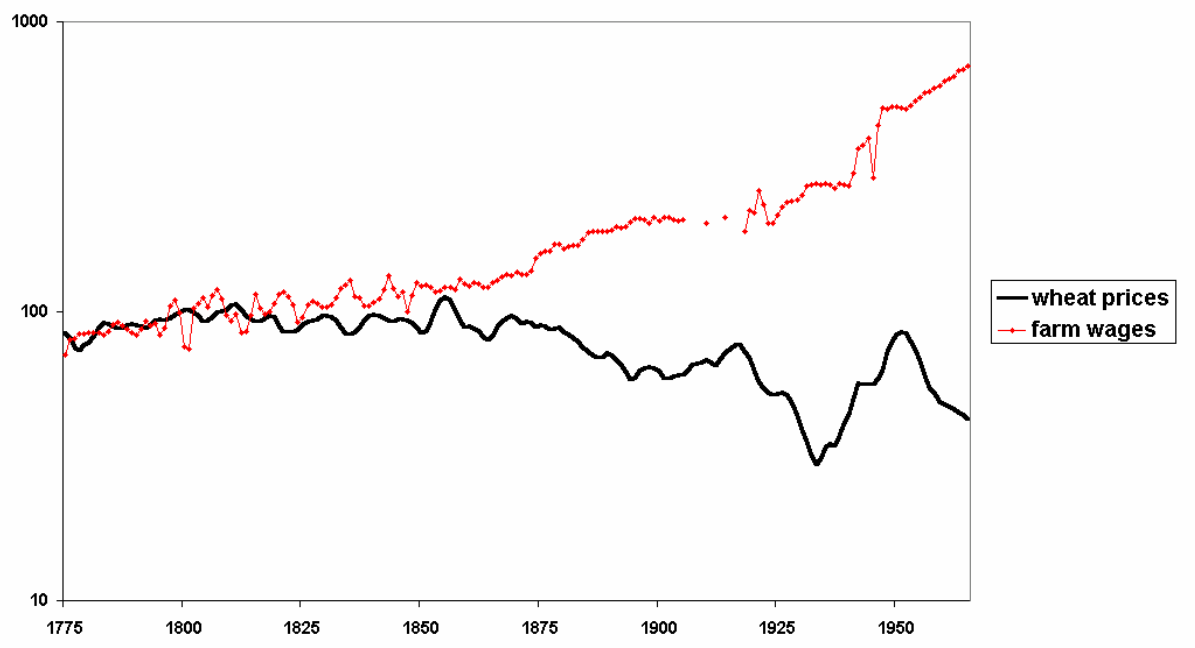

Source: Own calculations based on data in Mitchell (1975, pp. 191-5, 736; 1990, pp. 737-41, 756-7)

Figure 2. Real wheat prices (5-year moving average) and farm wages, United States. 1818=100

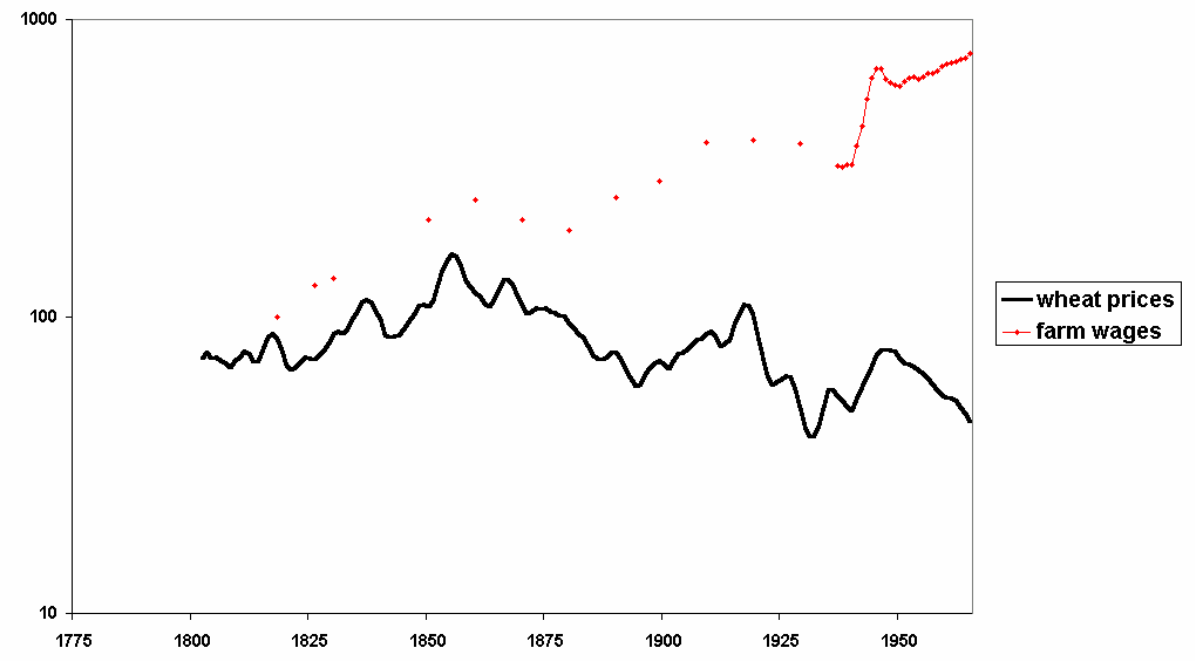

Source: Own calculations based on data in Mitchell (1993, pp. 129-30; 696-8) and US Bureau of the Census (1976, pp. 207-9)

Recent farm policy discussions have generated a new interest in this episode. Agricultural economists like Tracy (1989) have suggested that all western countries could have adjusted their 
agriculture in a free market, e.g. by shifting to livestock products which were more price-elastic than staples like grains. However, international markets for livestock products were soon overstocked by a few well-placed countries like Denmark and the Netherlands (Bairoch 1976). A few years after the fall in grain prices, livestock prices likewise declined. The free market adjustment thesis is also contradicted by the British experience. At the onset of the price fall around 1880, Britain possessed the most technically advanced agriculture in the world. However, industrial competition for labour had raised farm wages and the country no longer had a comparative advantage in agriculture. Nevertheless, until 1930, commercial interests and trade unions blocked a protectionist response. According to standard economic theory, free market adjustment might have involved a strong reduction, or even total elimination of agriculture, but if a farm sector managed to survive to some extent it would see a recovery of profits and productivity growth. In reality, farm profits remained low and productivity stagnated throughout this period (Koning 1994; van Zanden 1991; Wade 1981). This was not due to a technological ceiling, but to widespread disinvestment (Ó Gráda 1981; Offer 1989). Indeed, British agriculture fell far behind the European productivity frontier during this period (van Zanden 1991).

Supporters of the free market adjustment thesis have highlighted the negative effects of agricultural protection, especially in Germany (e.g. Gerschenkron 1966; Puhle 1986; Tracy 1989). Indeed, in a static analysis, agricultural protection caused deadweight losses and reduced the buying power of non-farm groups. However, a dynamic approach shows up matters in a different light. Productivity growth in German agriculture was among the highest in Europe (Helling 1966; Perkins 1981; Van Zanden 1991). Agricultural protection probably accelerated overall growth, allocational distortions being offset by an increase in effective demand (Bairoch 1976). Thereby, and because agriculture was relatively labour-intensive, the policy most likely raised real wages. ${ }^{5}$ Overall, the domestic effects of agricultural protection seem to have been quite favourable (see also Webb 1978). To be sure, protection alone did not enable farm progress. In France and Italy, where tenure relations gave little security to small farmers and where agricultural research and education lagged far behind those in Germany, productivity growth in farming was sluggish in spite of protection (Figure 3). ${ }^{6}$

A second fall of international agricultural prices around 1930 made all western countries resort to protection. By then, all of them had also engaged in government support of farm research, education and infrastructural programs, so that in these respects there was a policy convergence. The post-WWII years saw a further development of this constellation, aided by the general shift to social-Keynesian policies by which western countries responded to the traumatic experience of the 1930s and the communist challenge. Denmark and the United States briefly tried to return to free market policies in the 1950s, but these experiments were short lived and the outcomes disappointing (Cochrane \& Ryan 1976; Koning 1986 and literature referred to). After 1984, New Zealand abandoned protection. The adjustment was hailed as a success because it was followed by an increase in productivity growth (e.g. Federated Farmers 2002; Kalaitzandonakis 1994; Sandrey and Reynolds 1990). However, this increase was limited to horticulture and may have been due to pre-liberalization investments (Philpott 1994). In the livestock sector, productivity growth remained unaltered in spite of the massive release of marginal resources (ibid.; Lawrence and Diewert 1999; also cf. Cloke 1996; Gibson et al. 1994). It should be remarked that New Zealand has especially favourable conditions for dairy and horticulture. Its

\footnotetext{
${ }^{5}$ In any case, the negative effect on the costs of living of working-class households has been strongly overrated (Hentschel 1978). Something similar is true for the supposed harm to small livestock farmers Henning 1987, Moeller 1981, Webb 1982). Livestock production was not less protected than grain and grain tariffs did not drive up feed costs. Livestock was fed with fodder produced on the farm and with feedstuffs such as oil cakes, which were imported dutyfree.

${ }^{6}$ Nevertheless, the protection of agriculture seems to have sustained the demand for industrial products (Bairoch 1976). This was important, because French and Italian industries were more dependent on the domestic market than their British counterpart, which as the 'first workplace of the world' had gained an established position in the world market.
} 
production costs in dairy farming are only half those in other prominent dairy countries like the US, Denmark or the Netherlands (IFCN 2007). Moreover, the country benefited from the simultaneous introduction of the milk quota system in the EU, which reduced the share in the world dairy market of the latter from one-half to one-third. The New Zealand experience cannot be generalized, but was the exception that confirmed the rule.

\section{Figure 3. The growth of agricultural productivity per head and per hectare in eight countries of Western Europe, 1870-1910 (in wheat units and 1870 prices)}

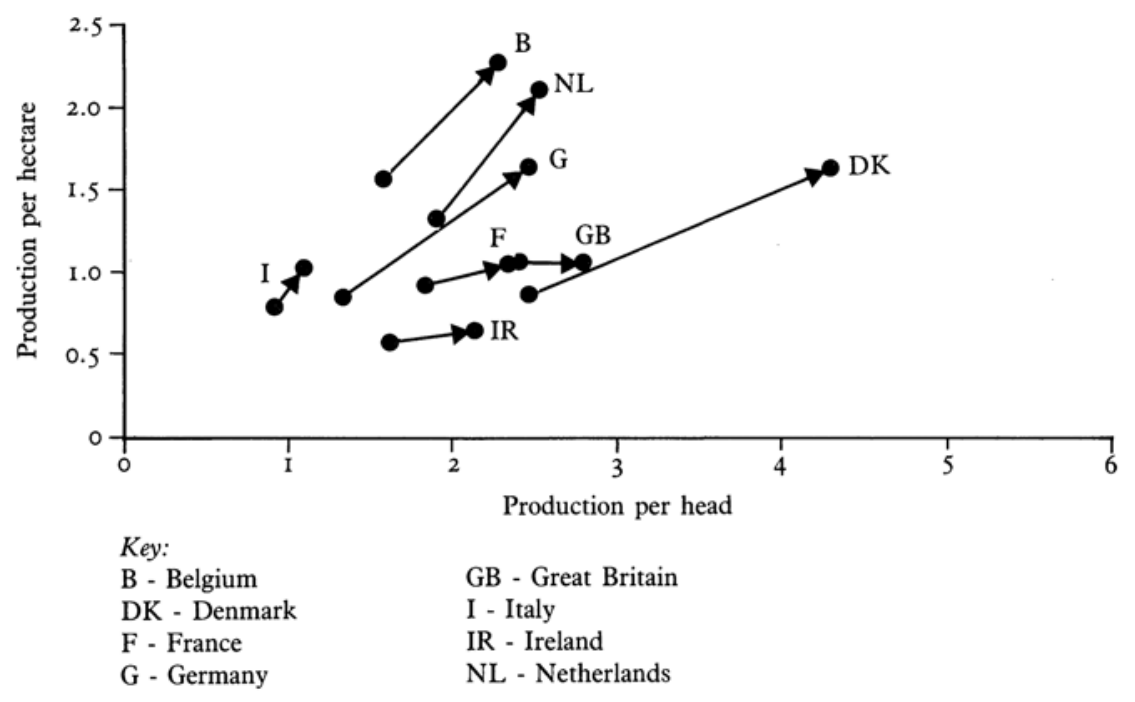

Source: Van Zanden (1991).

The introduction of price and development policies in western countries paved the way for a new agricultural revolution based on high yielding seeds, agri-chemicals and mechanization. Family farms rather than large farms were at the core of this revolution, and the increase in productivity was fastest where they had a strong position. The evolution of techniques and institutions adapted itself to family farms. Agricultural machinery was down-scaled, ${ }^{7}$ and scale-sensitive activities like brewing or cheese making were separated from primary agriculture. Agricultural cooperatives emerged as an interface that reduced transaction costs in the relations between family farmers and their buyers and sellers. ${ }^{8}$

The new model of agricultural development was only possible because government intervention overcame the risk-aversion of family farmers and their disadvantages in fields like information and consolidation, and mitigated the profit squeeze so that the frugality of family farmers left some margins for investment. Corporatist structures of negotiation and co-operation between government bodies and farmer organizations emerged to regulate state intervention in a small-scaled farming sector (Koning 1994). The combination of scientific research and family farmers also required some 'democratic' interface for being effective. The participatory county agent approach pioneered in the US in the early $20^{\text {th }}$ century (Scott 1970) became the prototype

\footnotetext{
${ }^{7}$ See e.g. Sahal (1981) and Williams (1987) for the tractor, or Hupfauer (1969) for the milking machine.

${ }^{8}$ It is striking that, from the end of the $19^{\text {th }}$ century, agricultural cooperatives mushroomed in many western countries, while before then they hardly existed (Smith 1961).
} 
for extension services in the western world, foreshadowing participatory approaches like farmer field schools that are now used in developing countries.

\section{Diverging responses in the developing world}

\section{East and South Asia}

The regime change that emanated from the 'western' world deeply affected other countries too, but the impacts varied depending on local conditions. In the pre-WWII Japanese Empire (which included Korea and Taiwan), the government stimulated farm progress, invested in irrigation and rural infrastructure, and protected its farmers at the outer border. It enabled significant rises in yields - even though these were moderated by rural inequality and the insecure position of small tenants - and made rural incomes an important demand factor for industries that produced simple goods for domestic consumption (Francks et al. 1999; Ohkawa and Rosovsky 1961; Ohkawa and Shinohara 1979). In post-war Japan, Korea and Taiwan, farmers benefited from redistributive land reforms and massive US aid, while high world market prices made negative protection less of a problem. After the Korean War, however, prices declined. Agricultural development in South Korea and Taiwan stagnated, entailing a slowdown of industrial growth. In both countries the government responded by stimulating industrial exports, but the recovery of industrial growth owed as much to a new rise in rural incomes. In Taiwan, this was due to large amounts of American aid being invested into agricultural infrastructure, research and extension (Thorbecke 1979), while in South Korea, it was also due to fertilizer subsidies, new import barriers, and a strong increase in rice prices paid by the government (Francks et al. 1999). When around 1970, agricultural growth slowed once more, both countries provided increasing protection to their farmers (Ban et al. 1980; Francks et al. 1999; Moon \& Kang 1991).

Like that in Germany before WWI, agricultural protection in South Korea and Taiwan has been blamed for freezing farming structures, retarding economic growth, and harming poor consumers (e.g. Anderson et al. 1986; Beghin et al. 2003; Diao et al. 2002; ERS-USDA 2002; Vincent 1989). These contentions are backed by standard equilibrium models, but the 'welfare losses' indicated by such models say nothing about how farm productivity, poverty or GDP would have evolved over time had farmers not been protected. Especially Taiwan is a paragon of successful agricultural diversification. In both countries, the increase in agricultural protection after 1970 was followed by new increases in farm output and incomes, and may well have caused the continuation of agriculture's contribution to the domestic demand pull for industrial growth, even if the relative importance of this contribution declined (Francks et al. 1999; Park \& Johnston 1995; also cf. Timmer 1995). ${ }^{9}$

While farmers in Japan, Korea and Taiwan were protected, those in Asian colonies of European countries were not. Low world market prices prevented population growth from raising agricultural prices, discouraging the farmer investment in sustainable land management on which earlier agricultural revolutions had been based. Studies like Geertz’ Agricultural involution

\footnotetext{
${ }^{9}$ The discussion on agricultural protection is related to that on industrial trade policies. Whereas advocates of 'industrial policy' point to the importance of infant-industry protection in the successful industrialization of the two countries (Amsden 1989; Rodrik 1994; Wade 1990), proponents of open-market regimes emphasize the encouragement of industrial exports that facilitated the acquisition of modern technology and skills (Berg and Krueger 2003; World Bank 1993) ${ }^{9}$. However, the precise relations between trade policies, exports and growth are far from clear (Edwards 1993). This leaves room for the hypothesis that agricultural protection, infant-industry protection and the encouragement of industrial exports have reinforced each other rather than conflicting with each other. Agricultural protection maintained the farm contribution to the domestic demand pull for industrialization. Domestic protection of industry prevented this effect from leaking away to other countries through increases in manufactured imports. Both together stimulated industrial growth, which facilitated the cross-subsidization of industrial exports as long as this was still needed to conquer the international markets. In this way, agricultural (and industrial) protection may well have contributed to the advantages of industrial exports that proponents of pro-market policies have emphasized.
} 
(1963) and Myrdal's Asian Drama (1968) highlighted the consequences. Rural societies were pushed in vicious spirals of poverty, population growth and/or resource degradation that suffocated economic development. This reminded of Malthusian crises like those in Europe in the $14^{\text {th }}$ and $17^{\text {th }}$ centuries. However, while these occurred because an agricultural revolution was exhausted, here an agricultural revolution was nipped in the bud.

Independence was a historical watershed. Several new governments introduced supportive farm policies (Dawe 2001; Dorward et al. 2001; Kajisa \& Akiyama 2005; Timmer 2002). At the same time, western governments started to export their new model of family farm based development stimulated by redistributive land reform, co-operatives and government sponsored research and extension. This was coupled to a growing flow of development aid, stimulated by the Cold War competition between the western and communist blocks. Part of this movement was the establishment of international agricultural research institutes like IRRI and CYMMIT that engaged in spreading the high-yielding seed revolution that had started with hybrid maize in the United States in the 1920s. The synergy of supportive national policies and high-yielding seeds from international research institutions led to the Green Revolution, which became an engine of industrialization. In China and Vietnam, a similar evolution became possible by the relaxation of policies that taxed agriculture for the sake of forced industrialization. ${ }^{10}$ The Green Revolution has been criticized for its negative side effects. Indeed, increased use of agrichemicals caused polluting emissions and quite some smaller farmers were displaced because they could not afford to buy the required package of purchased inputs. In themselves, these effects were similar to those of agricultural modernization in western countries, but in a setting where lack of entitlements was still a main cause of undernourishment, they could endanger rather than improve the food security of rural households that lost their means of existence. Nevertheless, there is no denial that the main effect of the Green Revolution on food security has been positive. By its domestic demand effect and other linkage effects, it became an engine of industrialization, which provided jobs and thereby access to food to those who had left the land. Overall, the share of poor and undernourished people in South and especially East Asia has strongly decreased.

That Asian countries choose to support their agriculture was connected to their socialpolitical structure. They had a long history of population growth, state formation, class differentiation and market development. Economic interests tended to organize on class basis, and the evolution of states had created a political class with an open eye for long-term interests. This political class and open or latent pressure from farmer movements became important pillars of the ‘developmental states’ (cf. Johnson 1987) that launched the Green Revolution.

\section{Latin America}

In the Americas, pre-Columbian Stone Age societies had been overrun by European invaders with superior weapons and diseases for which they had no immunity (Diamond 1998; Mann 2005). In the (sub)tropical parts, where profitable export crops could be grown that could not be produced in Europe, large plantations evolved that employed coercive labour systems to prevent workers from using the abundance of land and setting themselves up as independent peasants. It created a social divide between planter elites and rightless masses of rural workers, which encouraged 'oligarchic' political structures, hampered the development of simple consumer goods industries, and reinforced the export orientation of the plantations (de Janvry 1981). When international agricultural prices fell from the late $19^{\text {th }}$ century, agrarian elites kept to open trade policies (even though they engaged in cartelization attempts in coffee and sugar). Rather than calling for protection, they used their dominance to shift the burden to the rural poor. In the end, they evicted

\footnotetext{
${ }^{10}$ Of course, there are exceptions and variants to this pattern. In Thailand, abundance of land allowed agricultural growth without a Green Revolution (Siamwalla 1995), while in India, the Green Revolution was constrained by rural inequality and incomplete land reform (Patnaik 2002).
} 
large numbers of rural workers to pave the way for cost-cutting mechanization. This allowed a development of a kind, but one that involved more inequality and socio-political tensions than in other regions, as well as crowding and resource degradation in poor areas that served as a refuge for displaced rural workers. These effects curbed economic growth in the region (Johnston \& Kilby 1975; World Bank 2005). Land reform and conflicting trade policy interests of large and small farmers emerged as vital issues in this setting.

\section{Sub-Saharan Africa}

In Sub-Saharan Africa, endemic diseases and iron-armed warriors postponed the colonial scramble until the time that international agricultural prices declined. This limited the establishment of European-owned farms and plantations, as well as the evolution of larger indigenous farms. Africa's agriculture became even more a smallholder agriculture than it already was (Bundy 1972; Huijzendveld 1997; Munro 1976). Like in Asia, colonial governments failed to protect indigenous smallholder farmers. Relative abundance of land for some time provided an outlet for population growth, but this safety valve was gradually closed, and the fall in international agricultural prices around 1930 led to widespread alarm about soil degradation (Koning \& Smaling 2005 and literature referred to). Anti-erosion measures propagated by colonial officials went against the strategies by which farmers coped with low prices. Even in spite of coercion, therefore, these 'betterment policies' had little success (e.g. Mackenzie, 1998; Munro, 1975; Tiffen et al. 1994; more generally Koning \& Smaling 2005).

Higher post-war prices induced new investment by smallholder farmers, even though colonial governments used marketing boards for taxing farm exports to pay the expenses of their development apparatus (Munro 1976). In the 1960s, per capita incomes in Sub-Sahara Africa were higher than in Southern Asia. Unlike in Asia, however, national independence brought no real breach with colonial farm policies. Sub-Saharan African societies were little differentiated, had property rights in people rather than material assets, and had more fluid and personalist sociopolitical relations (Bayart 1989; Goody 1976). As a consequence, people tended to organize in clientelist factions rather than in class-based farmer movements. Politicians saw themselves obliged to remunerate large numbers of supporters with public sector jobs, while farmers were too weakly organized to prevent footing the bill (Bates 1981; Djurfeldt et al. 2005). Farmers were not protected and public investment in infrastructure for smallholder based development remained limited. Export crops were taxed to pay the expenses of an agricultural development apparatus that now became populated by African graduates but whose approaches still reminded of colonial 'betterment' (Bates 1981). The effects were felt when oil shocks raised the costs of farm inputs in the 1970s, and even more when international agricultural prices fell once more in the 1980s. Unfavourable price ratios and lack of infrastructure limited farmer investment in land management, which thereby failed to make the increase in population sustainable. The resulting agricultural stagnation became the core of a complex poverty trap. It caused a flight off the land, but squeezed the demand for domestic industries and services. As a consequence, the rural exodus was not absorbed by non-farm growth, but fueled political markets that were based on the doling out of public sector jobs (Koning 2002). State and semi-state bureaucracies increased, but falling export earnings and economic stagnation made this expansion bog down into fiscal crisis. Foreign lending gave briefly respite, but burdened the region with unsustainable debts.

There has been no lack of projects that tried to revitalize African agriculture. However, the results spread hardly beyond the artificial context of the project. Agronomists and other experts are struggling about which approach would be most suited to get agriculture moving high or low external inputs, farmer field schools or training and visit - but the reality is that all these approaches have disappointing results (Koning \& Smaling 2005; Reardon et al. 1999). Poor soils, adverse climates and diversified food patterns with roots and tubers in addition to cereals have been pointed to in attempts to explain these poor outcomes. Indeed, an agricultural revolution should be more diverse than in Asian circumstances - a 'Rainbow Evolution' rather 
than a Green Revolution (InterAcademy Council 2004). Nevertheless, natural conditions and food patterns can hardly explain why, e.g., in many places with fertile volcanic soils and a predominance of maize, rural societies are likewise stuck in stagnation. The real explanation of the plight of the region is the conjunction of international agricultural overproduction and patrimonial socio-political structures.

\section{Multilateral regulation of agricultural trade?}

Countries protect their farmers because international prices are low. Unless combined with supply management, however, protection further depresses international prices because it raises domestic production exacerbating the oversupply at the global level. The European countries that began protecting their farmers in the late 19th century hardly bothered about this. They were food importers, and if their policies reduced international prices they could simply raise their tariffs.

In the 1930s, however, major agricultural exporting countries also resorted to protection. Moreover, the Great Depression squeezed the domestic demand for farm products, leaving more countries with increasing surpluses. Because shrinking world markets made dumping increasingly costly for governments, several countries introduced supply management to reduce their excess production. Thus France controlled the production of wheat, the Netherlands that of livestock and vegetables, and the US that of cotton and tobacco. These measures soon became linked to international trade negotiations. Many policy makers and economists believed that some multilateral system of supply management was needed to bring world market prices back to desirable levels. The Monetary and Economic Conference of the League of Nations, the US Department of Agriculture in the New Deal Period, leading economist Keynes in his blueprint for the post-WWII economic order (Keynes 1943), and various UN bodies all advocated international commodity controls in one form or another. It led to the first international commodity agreements for staples like sugar and wheat, as well as to special provisions in the General Agreement on Tariffs and Trade (GATT) that was concluded after WWII (Chimni 1987; Gordon-Ashworth 1984; Henningson 1981). In spite of its free trade philosophy, the GATT permitted countries to protect their farmers provided that they controlled their production and exports. Besides, countries were allowed to engage in international commodity agreements to stabilize and support primary commodity prices if needed.

Nevertheless, a balanced multilateral system of managed trade did not emerge. Negotiations on international agreements for tropical crops were troubled because producer countries disagreed on quotas and consuming countries resisted anything beyond short-term price stabilization. Only a few control agreements were concluded. There were many challenges, but the main cause was rules that tilted the balance of power to importing countries and raised the costs of negotiating agreements. Agreements could only be negotiated on a commodity-bycommodity basis; their life time was bound to a 5 year limit; and they had to be approved by concurrent majorities of producing countries and consuming countries (Chimni 1987; Koning et al. 2004; Maizels 2002). In practice, this gave a veto to a few unwilling importing countries. In the 1970s, developing countries sought to redress this situation. They adopted a number of resolutions in the UN General Assembly and used UNCTAD to launch an Integrated Program for Commodities that envisaged the conclusion of 17 commodity agreements that were to be financed by a Common Fund for Commodities. Developed countries did not dare to withhold their signatures from this program, but they thwarted its implementation and let the few existing arrangements collapse in the 1980s (Chimni 1987; Gilbert 1996; Maizels 2002). ${ }^{11}$ Many economists see this history as proof that free rider and rent seeking problems make international commodity controls inherently unsustainable (e.g. Bohman et al. 1996; Herrmann 1986; Lal

\footnotetext{
${ }^{11}$ Except the agreement for natural rubber which lasted until 1999.
} 
1985). The evidence for this viewpoint is thin. Not only had few controls been introduced, but the resistance of importing countries to anything beyond short term price stabilization restricted the instruments to buffer stocks and export retention, which were not able to correct the supply for a longer period.

Meanwhile, the coupling of protection to production and export controls as intended by the GATT was thwarted by the expansionist policies of the US and the EU. Both blocks allowed their protectionist policies to entail import substitution and dumping (partly disguised as food aid). Around 1980, it caused a trade conflict between them. This was aggravated by growing US trade balance deficits and because the EU was free riding on the American acreage control program while the US was using the 'Rotterdam loophole' for dumping corn gluten on the European feed market (van den Noort 1995). ${ }^{12}$ The American government responded strategically by lowering its direct subsidization of farm exports and compensating farmers through price subsidies. On this base it could form a coalition with the 'Cairns group' of agricultural exporting countries that demanded the elimination of all export subsidies and import restrictions in the Uruguay Round of GATT negotiations. In 1993, a compromise between the US and the EU led to the WTO Agreement on Agriculture that prescribed reductions in price support measures but exempted certain forms of direct payments. In the following years, both powers increasingly replaced their price supports with such payments. Other countries could not follow this approach because of the high government cost involved, so that the obligatory reduction in price supports entailed a reduction in the support to their farmers. The Agreement on Agriculture gave developing countries some leeway for maintaining price supports. However, the US, the EU, the World Bank and the IMF have pressured them (in bilateral trade negotiations and negotiations on financial support) not to use this room. ${ }^{13}$ These developments were surrounded by a discourse which depicted this evolution as 'trade liberalization', harking back to realities of the mid- $19^{\text {th }}$ century. This reflected the shift from Keynesian to liberal-deflationary policies in global politics that was inaugurated by the Reagan and Thatcher administrations in the US and the UK (Monthly Review 1999). Model studies which showed that agricultural trade liberalization would bring 'welfare benefits', but that ignored the dynamics of agricultural markets and developing countries, played an important role in this discourse (e.g. Anderson \& Martin 2005; see FAO 2006 for criticism on these models). Meanwhile the income support given to OECD farmers has hardly decreased. While other countries are obliged to reduce their customs defenses, direct payments allow the US and the EU to continue exporting large volumes for prices below their own cost of production (Ray et al. 2003).

\section{Changes and continuity}

The reform of agricultural trade policies were part of a broader movement of farm policy liberalization. In addition to reductions in price supports, this also involved a dismantling of parastatals in developing countries, and a general shift from public to private agricultural research that was coupled to a strengthening of intellectual property rights (Pardey et al. 2006). These policy changes coincide with private sector changes. Until the 1980s, agri-food markets were mainly marked by chain differentiation, price competition and an increasing standardization of products. However, this pattern has been altering since under the influence of forces such as increased concentration in agro-industries and retailing, financial needs of highly capitalized farms, improved logistics, demand saturation, and ever stricter food safety requirements. These forces stimulate product differentiation and a new vertical coordination within agro-industrial

\footnotetext{
12 The 'Rotterdam loophole' was a loophole in the European system of agricultural import protection that was caused by the EU's commitment in the Dillon Round (1961-62) to allow free access to oilseeds and protein crops.

${ }^{13}$ This practice is still defended in the new World Development Report (World Bank 2007).
} 
chains that involves more buyer and seller interference with farm management (Barkema et al. 1993). Product differentiation also creates niches for new artisanal (including "organic" or "fair trade”) products, but that has remained a side effect.

Against these changes there is a vital continuity (Koning 1995). World agriculture is still marked by overproduction and a squeeze on farm profits. Claims by liberal economists that the problem of low farm earnings has ceased to exist (e.g. Gardner 1992; Hill 1996; OECD 2002) are based on data on total incomes of farm households that include income supports and do not measure the gap in factor returns between farming and non-farming. Although this gap tends to diminish as farmer communities become more strongly culturally integrated in urbanizing societies (Haagsma \& Koning 2005), the level of per capita GDP at which this occurs has increased rather than decreased over last decades (Timmer 2007).

New agro-industrial developments interact with the secular overproduction dynamics of agricultural markets. The increased market power of traders and processors causes farm-gate prices and final-consumer prices to diverge in various cases (e.g. Gouin 2007). Together with the loss of room for manoeuvre that quasi-integration involves for farmers, it reinforces the treadmill mechanism that generates overproduction. In its turn, overproduction weakens the market power of farmers against traders and processors, so that the two mechanisms become mutually reinforcing.

Rather than the alleged superior power of agrarian pressure groups that is blamed by liberal economists (e.g. Schmitt 1984; Senior Nello 1984; Tracy 1989; World Bank 2007), ${ }^{14}$ the continued squeeze on farm profits explains why, in spite of the liberal rhetoric, developed countries go on with supporting farm incomes. It also explains why the new chain coordination takes the form of a quasi-integration of agricultural production units of which the ownership is left with self-employed farmers. Real integration would allow lower production and transaction costs, but would saddle traders and processors with the low profitability of primary agriculture.

Although the recent changes have not ended the secular overproduction dynamics of agricultural markets to which public and private actors have to respond, they do have important effects. Demands of chain integrators are creating new thresholds for farm producers. This is even true for organic or fair trade chains, where high certification costs complicate the participation of resource-poor farmers (Clay et al. 2005).

Dismantling of price policies will entail increases in short-term price volatility, which will affect investment (Gérard et al. 2003; Boussard et al. 2006). Regrettably, no allowances have been made for such effects in the welfare-economic studies of agricultural trade liberalization that established institutions have made.

Liberal reforms have different effects in the developing world. Several successful Asian countries have become less dependent on farming and can moderate agricultural protection without endangering their economies (Dawe 2007). In Latin America, liberal-economic macropolicies and repression of popular opposition paved the way for new export-led growth based on large farms. In some cases, this generated new employment (see e.g. Anríquez \& López 2007 for horticulture in Chile), but in other cases, it created few additional job opportunities (see e.g. De Ferranti et al. 2005 for Brazil). In many places, low prices have driven many small farmers in illegal crops like coca, or turned them into new slum dwellers or illegal immigrants in the United States. Besides, the wild capitalism of the latifundio sector and the desperation of marginalized rural workers cause a scramble for fragile natural resources, leading to large-scale deforestation and depletion.

In Sub-Saharan Africa, the debt crisis allowed western donors to impose trade liberalization and reductions in government expenses. The latter were realized, first by cuts on public services, then by reductions in public sector wages, and only in the last place by public

\footnotetext{
${ }^{14}$ This idea is rooted in a false interpretation of Mancur Olson, who really pointed to the late development of agrarian countervailing power against urban power (see Olson 1985).
} 
sector retrenchment. Farmers suffered from competition by cheap imports and the neglect of roads and other public services. This only aggravated the agricultural crisis and the ensuing poverty trap in which the region was caught. It made access to and control over the public sector even more important for ambitious individuals, which aggravated the predatory tendencies in regional politics. Indeed, the "bad governance" bogey on which international donors are blaming the failure of their liberal prescriptions is partly of their own making.

Finally, the shift from public to private agricultural research is narrowing the room for agricultural development in less-favoured areas (Pingali 2007). Unlike the Green Revolution, the new Gene Revolution is led by corporations whose research agenda is guided by effective demand. It leads to massive investment in e.g. herbicide tolerance but to underinvestment in the drought resistance that is vital for millions of poor farmers in less-favoured dryland areas. Developing countries cannot easily compensate this through national research policies. While the germplasm of Green Revolution institutes like IRRI and CYMMIT was freely available for national researchers, the germplasm produced by private corporations is only available for those who are willing to pay the price.

\section{Long term global food availability: continued abundance or new scarcity?}

That agricultural markets are still marked overproduction, does not exclude a shift in the secular trend towards new scarcity in the future. Between now and mid-century, world population is expected to grow from 6.5 to 9 billion (United Nations 2005). Rising incomes in successful developing countries will boost the consumption of animal products, the global demand of which is expected to double (Steinfeld et al. 2006). Moreover, the use of biomass for new non-foods especially functionalized chemicals - will strongly increase. ${ }^{15}$ Together, these developments can easily lead to a tripling of the global demand for biomass.

There is no guarantee that this new increase in demand can be met effortlessly. To be sure, significant increases in farm output are still possible in many areas. Straightforward fertility measures, water-saving measures and pest management techniques would allow considerable yield increases in many dryland areas. Water-use efficiency in many irrigated systems could easily be doubled (Tuong et al. 2005). Simple storage and processing measures would reduce post-harvest losses and allow better residue use. And improved livestock systems could raise low feed ratios in developing countries (Wirsenius 2003). Nevertheless, the plentiful space for reclaiming new fertile lands, tapping water reserves for irrigation, and boosting yields through agro-chemicals and growth-resistant varieties on which the rapid increase in farm output in the $20^{\text {th }}$ century was based, are gradually being depleted. Only a few countries in South America and in Africa retain significant reserves of good lands (Fischer et al. 2001). Water is becoming increasingly limiting (Rosegrant et al. 2002). Mineral phosphate may become scarce (IFA/UNEP 1998; Smil 1999). And further increases in the yields of commercial staples are proving difficult to achieve (Bindraban 1997; Cassman et al. 2003).

From a purely technical viewpoint, the current global potential for farm production seems still to be adequate (Penning de Vries et al. 2005; Wolf et al. 2003). However, more than 80 percent of the technical reserves are situated in Latin America, Sub-Saharan Africa and transition countries, where their exploitation is complicated by institutional problems. Environmental constraints and technical complexities - e.g. of controlling pests and diseases - also hinder a full exploitation of the existing potential. ${ }^{16}$ In any case, a more far-reaching exploitation of this potential will involve significant increases in costs for irrigation and fertilization (Koning et al.,

\footnotetext{
${ }^{15}$ Biofuel and bioheat are much less efficient applications of biomass than functionalized chemicals (see Sanders et al. 2007).

${ }^{16}$ Even in Europe a quarter of crop production is still lost due to pests and diseases (Oerke et al. 1995).
} 
forthcoming).

The potential for biomass production could be stretched by technical breakthroughs that would raise the light or nutrient use efficiency of plants (e.g. Long et al. 2006) ${ }^{17}$ or by the development of new non-farm production systems based on e.g. seaweeds or algae (Reith et al. 2005; Spolaore et al. 2006). Alternatively, breakthroughs in biorefinement could increase the efficiency by which biomass is converted into foods or non-food products (Ragauskas et al. 2006; Sanders et al. 2007). However, investment in such technologies involves long gestation periods. The same is true for other investments that determine future production capacities, for instance in human capital or the regeneration of degraded soils. To avoid unnecessary scarcity, such investments should be taken in time. However, with myopic expectations and financially constrained farmers, low current prices can restrict the size of these investments. If, after some time, it were to become more difficult for the global supply of food to keep up with demand, this could lead to soaring food prices, wreaking havoc in net food importing poor countries. Such cobweb ('pig cycle') effects might be exacerbated if government support for agriculture were to be strongly reduced in a final phase of international overabundance (Koning et al., forthcoming). In this sense, the present dismantling of price supports, the continuance of disguised dumping by developed countries, the phasing out of fertiliser subsidies in developing countries and the worldwide reductions in support for farm research might pose serious threats.

\section{Which agricultural policies will enable global food security and sustainable pro-poor growth?}

Three main lessons can be drawn out of the above survey. Firstly, under the evolutionary regime that has prevailed since the late $19^{\text {th }}$ century, national and multilateral government intervention including price and income supports has become indispensable for a balanced development of the global agri-food economy. Secondly, different parts of the developing world are involved in different dynamic patterns, so that food security and sustainable pro-poor growth in these parts may require different types of intervention. Thirdly, it is not sure that the regime of abundant food supply at the global level will continue in the coming decades, so that responsible policies will have to reckon with the possibility of increased scarcity. These broad considerations can be translated in a number of general principles that are important if agricultural policies have to enable global food security and sustainable pro-poor growth.

\section{Policies for developing countries:}

- High- and middle-income countries should strongly increase their contribution to the funding of public international agricultural research. At the same time the agenda of this research should become much more focused on issues which are important for poor farmers and lessfavoured areas but that are being under-researched by private corporations. Drought resistance, orphan crops, and light irrigation in rainfed agriculture are likely candidates. Private corporations should be required to give access to their germplasm and exceptions to intellectual property rights should be made for these purposes.

- Public investment in roads, irrigation, farm research, extension, rural schools, health centres and other hard and soft infrastructures for agricultural progress in poor countries and lessfavoured areas should strongly increase. For example, African countries should realise their commitment made in Maputo in 2003 to use at least 10 percent of their budgets for agricultural development. This investment should be co-financed by international development aid.

- Where co-ordination problems cause a lack of private investment in supply and marketing

17 See however Yin \& Struik (2007) on over-optimistic expectations of the authors. 
chains for agricultural development in less-favoured areas, government participation can be needed to get things moving. This can mean that governments have to step back into some activities from which they have withdrawn in the frame of structural adjustment reform. However, sufficient room should be maintained for private competition to control bureaucratic tendencies, and governments should back out again as soon as private alternatives have grown strong enough.

- Rights of poor tillers should be strengthened to allow them to participate in and benefit from agricultural development. The priorities in this strengthening of rights follow from the different dynamic patterns in which parts of the developing world are involved. E.g., in Latin America with its strong inequalities in landownership, redistributive land reform and strengthening the land rights of poor farmers is a prominent issue. In Sub-Saharan Africa, however, priority may be given to corroborating local justice in ways that strengthen the rights of farm youths and women, to whom the burden of rural poverty tends to be shifted in gerontocratic structures. In emerging market economies in Asia, in their turn, social security regulations for farm workers may be most relevant.

- Developing countries should have the right to support the incomes of their farmers (also by protective tariffs) if this is needed to get their agriculture moving as an engine of growth. Additional government revenue that is generated by tariff increases should be used to enhance the public investment in hard and soft infrastructure for agricultural development. Any tariff increases on food imports should be accompanied by measures to compensate poor consumers. Roads building - financed through tariff revenue and international aid - can be used as employment projects for this purpose. Another possibility is school meals and other institutional meals made from domestic foods. Such measures can also give an important additional demand impulse for agricultural growth. Early estimates indicate that home-grown school feeding programs could raise the turnover of food crop farmers in Sub-Saharan Africa by some 15 percent.

- Participatory approaches are most suited as an interface between agricultural research and extension on the one hand, and smallholder farmers on the other hand. However, it should be understood that such approaches will only work when other enabling policy conditions (including public investment in infrastructure and supportive price policies) are also fulfilled.

Policies to reduce risks of strong rises in international food prices:

- Caution is needed in stimulating the demand for biomass for non-food purposes. A moderate increase in such demand that would cause some rise in international agricultural prices might stimulate agricultural development in poor countries. But a large increase in such demand could send international food prices skyrocketing. This could especially occur if government policies lead to large-scale production of biofuel. Preferably, the use of biomass for non-food should be limited to more efficient applications of biomass like functionalized chemicals. Rather than using seeds or tubers, second generation technologies for transforming residues and whole plants as could be developed. The conversion efficiency of biomass into chemicals could be greatly increased by fine-tuning and bio-refinery.

- Policies are required that mitigate the increasing claim on farm-produced biomass for animal foods for affluent consumers. A shift from beef to pork, poultry or fish would already moderate the competition with food for the poor (as well as improve public health). The development of more attractive plant-based meat substitutes (e.g. on the basis of fungi rather than grains and legumes) could have an even larger effect. Besides, new production systems for phytoplankton could moderate the demand for farm-produced feed (and fishmeal, which already claims almost half of the world's fish capture).

- Where possible nature and biodiversity conservation should be combined with agricultural exploitation. Large-scale conversion of agricultural land into nature/biodiversity reserves 
should happen in ways that make it readily reversible.

- To reduce the risk that, in the longer term, strong rises in international food prices cause havoc in poor net-food-importing countries, high- and middle-income countries should also increase their capabilities for agricultural production. Between now and mid-century, the global demand for food will double, while a larger share of suitable lands will be claimed for non-food purposes. The types of low input agriculture that are currently being developed as 'organic' alternatives for high input agriculture will not be able to meet the rising demand for food in the future. Agricultural research should aim at technologies for ecological modernization that reduce emissions while increasing land productivity rather than at techniques that reduce emissions by decreasing inputs while minimising production losses.

- Although countries should timely increase their capabilities for food production, they should make a restrained use of these capabilities as long as international markets are marked by abundant supply. (There is nothing contradictory in this: a reliable car has a strong engine as well as a strong brake.) High- and middle-income countries should have the right to support the incomes of their farmers to enable a precautionary policy of enhancing production capabilities with a view to any future increases in global scarcity, but only if they use these capabilities with constraint in order to avoid global overproduction.

Multilateral regulation of agricultural markets and trade:

- Simple 'liberalization' is not a viable concept for a multilateral system of agricultural trade in the current situation, and leads to an unbalanced situation of disguised dumping by rich countries and customs disarmament of poor countries.

- A multilateral system of managed trade based is needed to keep international agricultural prices within desirable price bands. In tropical export crops this means the establishment of international production controls based on export and production controls. In other crops, the introduction of supply management should start by imposing disciplines on developed countries to correct trade distortions that have been caused by decennia-long policies of offensive protection,. E.g., maximum export quotas and minimum import quotas could be imposed on developed countries, with quotas based on historical trade volumes and tradable between governments. After a transition period, such disciplines could be extended to middle-income countries. Low-income countries should be exempted to create room for them to increase their production and exports.

- To prevent the demand of the affluent for animal products and nonfoods to outcompete the demand for food for the poor, an international tax on the use of biomass for new nonfoods could be introduced that is levied when international prices of food staples exceed a preagreed ceiling.

\section{References}

- $\quad$ W. Abel, Agrarkrisen und Agrarkonjunktur. Eine Geschichte der Land- und Ernährungswirtschaft Mitteleuropas seit dem hohen Mittelalter. Hamburg and Berlin 1978.

- $\quad$ Akerlof, G.A., and J.L. Yellen (1986). Efficiency wage models of the labor market. Cambridge: Cambridge University Press.

- $\quad$ Amsden, A.H., Asia's next giant: South Korea and late industrialization, New York 1989.

- Anderson, K., Hayami, Y., George, A., Honma, M. and Otsuka, K, The political economy of agricultural protection : East Asia in international perspective, Sydney etc. 1986.

- $\quad$ K. Anderson \& W. Martin, 'Agricultural trade reform and the Doha Development Agenda', The World Economy, vol. 28 (2005)9 1301-1327.

- $\quad$ Anríquez, G., \& R. López, "Agricultural Growth and Poverty in an Archetypical Middle Income Country: Chile 1987-2003", Agricultural Economics, 36 (2007)2 191-202.

- $\quad$ Bairoch, P., Commerce extérieur et developpement économique de lÉurope au XIXe siècle, Paris 1976. 
- $\quad$ Ban, S.H., P.Y. Moon and D.H. Perkins, Rural development. Studies in the modernization of the Republic of Korea: 1945-1975, Cambridge (Mass.) and London 1980.

- $\quad$ Barkema, A, et al., 1993. "The industrialization of the U.S. food system". In: D.I. Padberg (ed.), Food and agricultural marketing issues for the 21th century, Texas A\&M University, College Station, pp. 3-20.

- $\quad$ R.H. Bates, Markets and states in tropical Africa: the political basis of agricultural policies, Berkeley 1981.

- $\quad$ J.-F. Bayart, L'Etat en Afrique: la politique du ventre, Paris 1989.

- $\quad$ Beghin, J.C., Bureau, J.-C. and Park, S.J., 'Food security and agricultural protection in South Korea', American Journal of Agricultural Economics, vol. 85 (2003)3 618-632.

- $\quad$ Berg, A. \& A. Krueger, Trade, growth, and poverty: a selective survey, IMF Working Paper WP/03/30, February 2003.

- $\quad$ P.S. Bindraban, Bridging the gap between plant physiology and breeding: identifying traits to increase wheat yield potential using systems approaches, dissertation Wageningen University 1997.

- $\quad$ Bohman, M., Jarvis, L. \& Barichello, R., 'Rent seeking and international commodity agreements: the case of coffee', Economic Development and Cultural Change, vol. 44(1996)2 379-404.

- $\quad$ J.-M. Boussard, F. Gérard, M.G. Piketty, M. Ayouz \& T. Voituriez, 'Endogenous risk and long run effects of liberalization in a global analysis framework’, Economic Modelling 23 (2006) 457-475.

- $\quad$ C. Bundy, 'The emergence and decline of a South African peasantry’, African Affairs, vol. 71 (1972) pp. 369-388.

- $\quad$ B.S. Chimni, International commodity agreements: a legal study, London etc. 1987.

- Cassman KG, Dobermann A, Walters DT, Yang H, 2003, "Meeting cereal demand while protecting natural resources ad improving environmental quality”, Annual Review of Environment and Resources 28 (2003) 315-358

- $\quad$ J.W. Clay, A. Dufey \& J. MacGregor, "Leverage points for encouraging sustainable commodities”, in T. Lines (ed.), Agricultural commodities, trade and sustainable development, IIED \& ICTSD, London and Geneva 2005 201-226.

- $\quad$ Cloke, P., 1996. 'Looking through European eyes? A re-evaluation of agricultural deregulation in New Zealand'. Sociologia Ruralis, vol. 36: 305-330.

- $\quad$ Cochrane, W.W. 1959. Farm prices - myth and reality, Minneapolis.

- $\quad$ Cochrane, W.W., and M.E. Ryan, 1976. American farm policy, 1948-1974. Minneapolis.

- $\quad$ Crosby, T.L., English farmers and the politics of protection, 1815-52, Hassocks 1977.

- D. Dawe, 'How far down the path to free trade? The importance of rice price stabilization in developing Asia', Food Policy, vol. 26 (2001)2 163-175.

- D. Dawe, 'The practical experience with agricultural trade liberalization in Asia', in N. Koning \& P. PinstrupAndersen (eds), Agricultural trade liberalization and the least developed countries, Dordrecht 2007.

- De Ferranti, David, Guillermo E. Perry, William Foster, Daniel Lederman, \& Alberto Valdés. 2005. Beyond the City: The Rural Contribution to Development. Washington, D.C.: World Bank.

- $\quad$ De Janvry, A., (1981). The agrarian question and reformism in Latin America. Baltimore.

- $\quad$ J. Diamond, Guns, germs and steel: a short history of everybody for the last 13,000 years, London etc. 1998.

- $\quad$ X. Diao, J. Dyck, D. Skully, A. Somwaru C. Lee, Structural change and agricultural protection: costs of Korean agricultural policy, 1975 and 1990, USDA Agricultural Economic Report number 809, Washington, DC, March 2002.

- $\quad$ Directie van den Landbouw, Een en ander betreffende de regeeringsbemoeiingen in zake den landbouw, The Hague 1907.

- $\quad$ Djurfeldt, G. Holmen H., M. Jirstroml, and R. Larsson, eds. 2005. The African Food Crisis: Lessons from the Asian Green Revolution, London.

- $\quad$ Dorward, A., J. Kydd, J.A. Morrison \& I. Urey, A policy agenda for pro-poor agricultural growth, Paper presented at the Agricultural Economics Society Conference, Aberystwyth, $8^{\text {th }}-10^{\text {th }}$ April 2001.

- $\quad$ Dovring, F., Land and labor in Europe in the twentieth century. A comparative survey of recent agrarian history, The Hague 1965.

- $\quad$ Edwards, S., 'Openness, trade liberalization, and growth in developing countries', Journal of Economic Literature, vol. 31 (1993) 1358-1393.

- $\quad$ ERS-USDA, 'South Korea’s agricultural policy hampered economic growth', Agricultural Outlook, June-July 2002, 10-13.

- $\quad$ FAO, Towards appropriate agricultural trade policy for low-income developing countries, FAO Trade Policy Technical Notes no. 14, Rome 2006.

- $\quad$ Federated Farmers of New Zealand, 2002. Life after subsidies: the New Zealand experience 15 years later. http://www.fedfarm.org.nz/documents/LifeAfterSubsidiesAug02.pdf.

- $\quad$ G. Fischer, M. Shah, H. van Velthuizen \& F.O. Nachtergaele, Global agro-ecological assessment for agriculture in the $21^{\text {st }}$ century, IIASA \& FAO, Vienna 2001.

- $\quad$ Francks, P., Boestel, J. and Kim C.H., Agriculture and economic development in East Asia: from growth to protectionism in Japan, Korea and Taiwan, London and New York 1999.

- $\quad$ Gardner, B. L., “Changing perspectives on the farm problem”, Journal of Economic Literature 30 (1992) 62-101.

- $\quad$ C. Geertz, Agricultural involution: the processes of ecological change in Indonesia, Berkeley and Los Angeles 1963. 
- Gérard, M-G. Piketty \& J.M. Boussard, 'Libéralisation des échanges et bien-être des populations pauvres: illustration à partir du modèle $\mathrm{ID}^{3}$ de la faiblesse des impacts et de la sensibilité des resultants aux hypotheses de fonctionnement des marchés', Notes et Études Économiques, no. 19 (2003) 111-134.

- $\quad$ Gerschenkron, A., Bread and democracy in Germany, New York 1966.

- $\quad$ Gibson, J., et al., 1992. Agricultural and trade deregulation in New Zealand: lessons for Europe and the CAP, paper for the 28th EAAE Seminar, 'EC agricultural policy by the end of the century', Lisboa, September 10-12.

- $\quad$ Gilbert, C.L. (1996). 'International commodity agreements: an obituary notice', World Development, vol. 24 nr 1 1-19.

- $\quad$ J. Goody, Production and reproduction: a comparative study of the domestic domain, Cambridge etc. 1976.

- Gordon-Ashworth, F. (1984). International commodity control: a contemporary history and appraisal, London etc.: Croom Helm \& St. Martin's Press.

- Gouin, D.-M., « La gestion de l'offre dans le secteur laitier : un système de régulation toujours pertinent », in J.M. Boussard \& H. Delorme (eds), La régulation des marchés agricoles internationaux : un enjeu décisif pour le développement, Paris 2007.

- $\quad$ Grigg, D., Population growth and agrarian change: an historical perspective, Cambridge etc. 1980.

- Haagsma, R. \& Koning, N. (2002). 'Endogenous mobility-reducing norms', Journal of Economic Behavior \& Organization, vol. 49 pp. 523-547.

- $\quad$ Haagsma, R., \& N. Koning, “Endogenous norms and preferences and the farm income problem”, European Review of Agricultural Economics, 32 (2005)1 25-49.

- Herrmann, R. (1986). 'Free riders and the redistributive effects of international commodity agreements: the case of coffee’, Journal of Policy Modelling, vol. 8 (4) 597-621.

- InterAcademy Council, Realizing the Promise and Potential of African Agriculture: Science and Technology Strategies for Improving Agricultural Productivity and Food Security in Africa, Amsterdam 2004.

- Helling, G., 'Zur Entwicklung der Produktivität in der Landwirtschaft im 19. Jahrhundert', Jahrbuch für Wirtschaftsgeschichte, 1966-1 129-141.

- Henning, F.-W., 'Vom Agrarliberalismus zum Agrarprotektionismus', in H. Pohl (ed.), Die Auswirkungen von Zöllen und anderen Handelshemmnissen auf Wirtschaft und Gesellschaft vom Mittelalter bis zur Gegenwart, Stuttgart 1987 252-274.

- $\quad$ Henningson, B.E. jr., 1981. United States agricultural trade and development policy during world war II: the role of the Office of Foreign Agricultural Relations, Ph.D. diss., University of Arkansas.

- Hentschel, V., Wirtschaft und Wirtschaftspolitik im wilhelminischen Deutschland: Organisierter Kapitalismus und Interventionsstaat?, Stuttgart 1978.

- Hill, B., 'Monitoring incomes of agricultural households within the EU's information system - new needs and new methods', European Review of Agricultural Economics, vol. 23 (1996) 27-48.

- Huijzendveld, F.D., 'Die ostafrikanische Schweiz': Plantages, planters en plattelandsontwikkeling in WestUsambara, Oost-Afrika, ca. 1870-1930, N.W. Posthumus Reeks nr 7, Amsterdam 1997.

- Hupfauer, M., “Milchgeräte”, in G. Franz (ed.), Geschichte der Landtechnik im 20. Jahrhundert, Frankfurt am Main 1969 423-439.

- $\quad$ IFA/UNEP, The fertilizer industry, world food supplies and the environment, Paris 1998.

- $\quad$ IFCN, Dairy report 2006, Braunschweig 2003.

- Johnson, A.W., \& T. Earle, The evolution of human societies: from foraging group to agrarian state, Stanford 2000.

- Johnson, C., 'Political institutions and economic performance: a comparative analysis of the government-business relationship in Japan, South Korea and Taiwan', in F. Deyo (ed.), The political economy of the new Asian industrialism, Ithaca 1987 136-164.

- $\quad$ B.F. Johnston and P. Kilby, Agriculture and structural transformation; economic strategies in late-developing countries, New York etc. 1975.

- $\quad$ Kajisa, K., \& T. Akiyama, "The evolution of rice price policies over four decades: Thailand, Indonesia and the Philippines”, Oxford Development Studies, 33 (2005)2.

- $\quad$ Kalaitzandonakes, N.G., 'Price protection and productivity growth, American Journal of Agricultural Economics, vol. 76 (November 1994) pp. 722-732.

- Keynes, J.M. (1943). 'The international regulation of primary products', reprinted in D. Moggridge (ed.), Collected writings of John Maynard Keynes, London 1980: MacMillan \& Cambridge University Press.

- $\quad$ Koning, N., 1986. 'Beperkingen van landbouwinkomenspolitiek in kapitalistische industrielanden', Tijdschrift voor Sociaalwetenschappelijk Onderzoek van de Landbouw, vol. 1 pp. 113-133.

- $\quad$ N. Koning, The failure of agrarian capitalism: agrarian politics in the United Kingdom, Germany, the Netherlands and the USA, 1846-1919, London and New York 1994.

- Koning, N., "Fordism, 'post-Fordism', and the agrarian question”, Proceedings of the Congress 'Agrarian Questions': the politics of farming anno 1995, vol. 2, Wageningen Agricultural University 1995 812-836.

- $\quad$ Koning, N., 2002. Should Africa protect its farmers to revitalise its economy? IIED Gatekeeper Series no. 105, London. 
- $\quad$ N. Koning, M. Calo \& R. Jongeneel, Fair trade in tropical crops is possible: international commodity agreements revisited, North-South discussion paper no. 3, Wageningen 2004.

- $\quad$ Koning, N. \& E. Smaling, 'Environmental crisis or 'lie of the land'? The debate on soil degradation in Africa', Land Use Policy 22 (2005)1 3-11.

- $\quad$ Koning, N., G. Becx, T. van Boekel, W. Brandenburg, J. van den Broek, G. van Hofwegen, M. van Ittersum, R. Jongeneel, H. Schiere, M. Smies, Long-term global availability of food: continued abundance or new scarcity?, forthcoming.

- $\quad$ Lal, D., The poverty of development economics, Cambridge (Mass.) 1985.

- $\quad$ Lawrence, D. and Diewert, E. 1999. Measuring New Zealand's productivity. Report prepared for the Department of Labour, Reserve Bank of New Zealand and the Treasury

- $\quad$ Long SP, Zhu XG, Naidu SL, Ort DR, 2006, “Can improvement in photosynthesis increase crop yields?” Plant Cell and Environment 29 (3): 315-330 MAR

- $\quad$ Mackenzie, A.F.D., 1998. Land, ecology and resistance in Kenya, 1880-1952, Edinburgh.

- Maizels, A. (1992). Commodities in crisis: the commodity crisis of the 1980s and the political economy of international commodity policies, Oxford: Clarendon Press.

- $\quad$ C.C. Mann, 1491 : new revelations of the Americas before Columbus, New York 2005.

- $\quad$ M. Mazoyer \& L. Roudart, Histoire des agricultures du monde; du néolithique à la crise contemporaine, Paris 1997.

- J.-M. Meuvret, 'Les crises de subsistances et démographie de la France d’Ancien Régime’, Population, vol. 2 (1946) 643-650.

- $\quad$ Mitchell, B.R., European historical statistics, Cambridge 1975.

- $\quad$ Mitchell, B.R., British historical statistics, Cambridge 1990.

- $\quad$ Mitchell, B.R., 1993. International historical statistics: the Americas, 1750-1988, New York.

- $\quad$ Moeller R.G., 'Peasants and tariffs in the Kaiserreich: how backward were the Bauern', Agricultural History, vol. 55 (1981), 4 370-384.

- $\quad$ Monthly Review 51 (1999) 3, Capitalism at the end of the millennium: a global survey.

- Moon, P.Y. and B.S. Kang, 'The Republic of Korea', in A. Krueger, M. Schiff and A. Valdés, The political economy of agricultural pricing policy, vol. 2: Asia, Baltimore and London 1991.

- $\quad$ Moore, D.C., « The corn laws and high farming », Economic History Review, 18 (1965) 544-561.

- $\quad$ Munro, J.F., 1975. Colonial rule and the Kamba: social change in the Kenya highlands, 1889-1939, Oxford.

- J.F. Munro, Africa and the international economy 1800-1960; an introduction to the modern economic history of Africa south of the Sahara, London and Totowa 1976.

- $\quad$ G. Myrdal, Asian drama : an inquiry into the poverty of nations, New York 1968.

- $\quad$ Noort, P.C. van den, 1995. 'Spanningen in het internationale graankartel'. In P.C. van den Noort en N.B.J. Koning, Landbouw en algemeen belang. Syllabus bij het college kennis van landbouwpolitiek, LU Wageningen, pp. 27-37.

- $\quad$ OECD, Farm household income: issues and policy responses, Paris 2002.

- $\quad$ E.C. Oerke, H.W. Dehne, F. Schohnbeck \& A. Weber, Crop production and crop protection: estimated losses in major food and cash crops, Amsterdam 1995.

- $\quad$ Offer, A., The First World War: an agrarian interpretation, Oxford 1989.

- $\quad$ Ó Gráda, C., 'Agricultural decline 1860-1914', in R. Floud and D. McCloskey (eds), The economic history of Brian since 1700. Part 2: 1860s to the 1970s, Cambridge etc. 1981, pp. 175-197.

- Ohkawa, K. and H. Rosovsky, 'The indigenous components in the modern Japanese economy', Economic Development and Cultural Change, vol. 9 (1961)3 476-501.

- $\quad$ Ohkawa, K. and M. Shinohara, Patterns of Japanese economic development: a quantitative appraisal, New Haven 1979.

- $\quad$ Olson, M., “Space, agriculture and organization”, American Journal of Agricultural Economics 67 (1985) 928937.

- $\quad$ P.G. Pardey, N. Beintema, S. Dehmer \& S. Wood, Agricultural research: a growing global divide? IFPRI, Washington D.C., 2006.

- $\quad$ Park, A. and B. Johnston, 'Rural development and dynamic externalities in Taiwan's structural transformation', Economic Development and Cultural Change, vol. 44 (1995) 181-208.

- $\quad$ Patnaik, U., “The agrarian question and the development of capitalism in India”, in A. Thorner (ed.), Land, labour and rights; Daniel Thorner memorial lectures, Tulika 2002.

- $\quad$ Penning de Vries, F., et al., 1995. 'Natural resources and limits of food production in 2040', in J. Bouma et al. (eds.), Eco-regional approaches for sustainable land use and food production, Dordrecht etc., 65-87.

- $\quad$ Perkins J.A., 'The agricultural revolution in Germany, 1850-1914', Journal of European Economic History, vol. 10 (1981)1 71-118.

- $\quad$ Philpott, B., 1994. Productivity growth by type of farming: 1972-1993, Research Project on Economic Planning paper 259, Wellington.

- $\quad$ P. Pingali, Mansholt lecture, Wageningen 2007.

- $\quad$ H.-J. Puhle, 'Lords and peasants in the Kaiserreich', in R.G. Moeller (ed.), Peasants and lords in modern Germany: recent studies in agricultural history, Winchester (Mass.) 1986 81-109. 
- $\quad$ Ragauskas AJ, Williams CK, Davison BH, Britovsek G, Cairney J, Eckert CA, Frederick WJ, Hallett JP, Leak DJ, Liotta CL, Mielenz JR, Murphy R, Templer R, Tschaplinski T, 2006, “The path forward for biofuels and biomaterials”, Science 311 (5760): 484-489 JAN 272006.

- $\quad$ D. Ray, D. De La Torre Ugarte ,K. Tiller, 2003. Rethinking U.S. Agricultural Policy: Changing course to secure farmers livelihoods worldwide, University of Tennessee, Knoxville.

- $\quad$ Reardon, T., Barrett, C., Kelly, V., Savadogo, K., 1999. Policy reforms and sustainable agricultural intensification in Africa. Development Policy Review 17, 375-395.

- $\quad$ J.H. Reith, E.P. Deurwaarder, K. Hemmes, A.P.W.M. Curvers, P. Kamermans, W. Brandenburg, G. Zeeman, Biooffshore; Grootschalige teelt van zeewieren in combinatie met offshore windparken in de Noordzee, ECN/WUR 2005.

- $\quad$ D. Ricardo, Principles of political economy and taxation, London 1817.

- $\quad$ Rodrik, D., King Kong meets Godzilla: the World Bank and the East Asian Miracle, CEPR Discussion Paper no. 944, 1994.

- $\quad$ M.W. Rosegrant, X. Cai \& S.A. Cline, World water and food to 2025: dealing with scarcity, IFPRI, Washington, DC 2002.

- $\quad$ Rossiter, M.W., “The organization of the agricultural sciences”, in A. Oleson \& J. Voss (eds), The organization of knowledge in modern America, 1860-1920, Baltimore 1979 211-248.

- $\quad$ Sahal, D., “The farm tractor and the nature of technological innovation”, Research Policy 10 (1981) 369-402.

- $\quad$ Sanders, J., E. Scott, R. Weasthuis \& H. Mooibroek, 'Bio-refinery as the bio-inspired process to bulk chemicals', Macromolecular Bioscience, 20077 105-117.

- $\quad$ Sandrey, R. and Reynolds, R. 1990. Farming without subsidies: New Zealand's recent experience. MAF Policy Services, Wellington.

- $\quad$ Schling-Brodersen, U., Entwicklung und Institutionalisierung der Agrikulturchemie im 19. Jahrhundert: Liebig und die landwirtschaftlichen Versuchsstationen, Braunschweiger Veröffentlichungen zur Geschichte der Pharmazie und der Naturwissenschaften, Band 31, Braunschweig 1989.

- $\quad$ Schmitt, G., "Warum die Agrarpolitik ist wie sie ist, und nicht wie sie sein sollte”, Agrarwirtschaft 33 (1984) 129136.

- $\quad$ Th.W. Schultz, Agriculture in an unstable society, New York and London 1945.

- $\quad$ Schutkowski, Human ecology: biocultural adaptations in human communities, Springer: Berlin etc. 2006.

- $\quad$ Scott, R.V., The reluctant farmer: rise of agricultural extension to 1914, Urbana etc. 1970.

- Senior Nello, S., "An application of public choice theory to the question of CAP reform”, European Review of Agricultural Economics 11 (1984) 261-283.

- $\quad$ R.S. Shiel, 'Improving soil productivity in the pre-fertilizer era', B.M.S. Campbell and M. Overton (eds), Land, labour and livestock: historical studies in European agicultural productivity, Manchester and New York 1991, pp. 51-77.

- Siamwalla, A., "Land-abundant growth and some of its consequences: the case of Thailand”, in J. Mellor (ed.), Agriculture on the road to industrialization, Baltimore \& London 1995.

- $\quad$ B.H. Slicher van Bath, The agrarian history of Western Europe, A.D. 500-1850. London 1963.

- V. Smil, Long-range perspectives on inorganic fertilizers in global agriculture. 1999 Travis P. Hignett Lecture, IFDC, Florence (Alabama) November 1, 1999.

- $\quad$ Smith, L.P.F., The evolution of agricultural co-operation, Oxford 1961.

- $\quad$ Smith, T.L., "Farm labour trends in the United States, 1910-1969”, International Labour Review 102 (1970)2 149169.

- $\quad$ Spolaore P, Joannis-Cassan C, Duran E, Isambert A, 2006, Commercial applications of microalgae, Journal of Bioscience and Bioengineering 101 (2): 87-96 FEB .

- H. Steinfeld, P. Gerber, T. Wassenaar, V. Castel, M. Rosales \& C. de Haan, Livestock’s long shadow; environmental issues and options, FAO, Rome 2006.

- $\quad$ Sykes, J.D., “Agriculture and science”, in G.E. Mingay (ed.), The Victorian countryside, London etc. 1981 $260-272$.

- $\quad$ Thorbecke, E., 'Agricultural development', in W. Galenson (ed.), Economic growth and structural change in Taiwan, London 1979.

- $\quad$ Tiffen, M., Mortimore, M., Gichuki, F., 1994. More People, Less Erosion: Environmental Recovery in Kenya. Wiley, London.

- $\quad$ Timmer, C.P., 1995. Getting agriculture moving: do markets provide the right signals? Food Policy, 20: 455-472.

- Timmer, CP, Food security and rice price policy in Indonesia: the economics and politics of the food price dilemma, Indonesian Food Policy Program Working Paper no. 7, Bappenas/USAID/DAI Food Policy Advisory Team, 2002.

- Timmer, C.P., A World without agriculture: the structural transformation in historical perspective, Wendt Lecture, May 8, 2007, American Enterprise Institute, Washington, DC.

- $\quad$ T.P. Tuong, B.A.M. Bouman \& M. Mortimer, 'More rice, less water - integrated approaches for increasing water productivity in irrigated rice-based systems in Asia', Plant Production Sciences, vol. 8(2005)3 229-239.

- $\quad$ United Nations, World population prospects: the 2004 revision, 2005 (b) (http://esa.un.org/unpp/). 
- $\quad$ US Bureau of the Census, 1976. The statistical history of the United States from colonial times to the present, New York.

- Van Zanden, J.L., 1991. 'The first Green Revolution: the growth of production and productivity in European agriculture, 1870-1914’. Economic History Review, vol. 44: 215-239.

- Vincent, D., 'Domestic effects of agricultural protection in Asian countries with special reference to Korea', in A.B. Stoeckel, D. Vincent and S. Cuthbertson (eds), Macroeconomic consequences of farm support policies, Durham 1989 150-172.

- $\quad$ Wade, R., Governing the market: economic theory and the role of the government in East Asian industrialization, Princeton (N.J.) 1990.

- W.W. Wade, Institutional determinants of technical change and agricultural productivity growth: Denmark, France and Great Britain, 1870-1965, New York 1981.

- Williams, R.C., Fordson, Farmall, and Poppin' Johnny: a history of the farm tractor and its impact on America, Champaign 1987.

- $\quad$ S. Wirsenius, 'Efficiencies and biomass appropriation of food commodities on global and regional levels', Agricultural Systems, vol. 77 (2003) 219-255.

- Wolf J, Bindraban PS, Luijten JC, 2003, Vleeshouwers LM, Exploratory study on the land area required for global food supply and the potential global production of bioenergy, Agricultural Systems 76: 841-861

- $\quad$ Wood, J.W., “A theory of preindustrial population dynamics”, Current Anthropology, 39 (1998) 99-135.

- $\quad$ World Bank, The East Asian miracle: economic growth and public policy, Oxford 1993.

- $\quad$ World Bank, Equity and development, World Development Report 2006, Washington D.C. 2005.

- $\quad$ World Bank, World development report 2008: agriculture for development, yellow cover draft, Washington D.C. 2007.

- Yin X, Struik PC, “Crop systems biology - an approach to connect functional genomics with crop modeling”, in Spiertz, J.H.J., Struik, P.C., Laar, H.H. van (Eds), Scale and Complexity in Plant Systems Research, Dordrecht 2007. 